\title{
Sandhill Crane Nesting at Rokeby Marsh
}

by DR. STUART HOUSTON

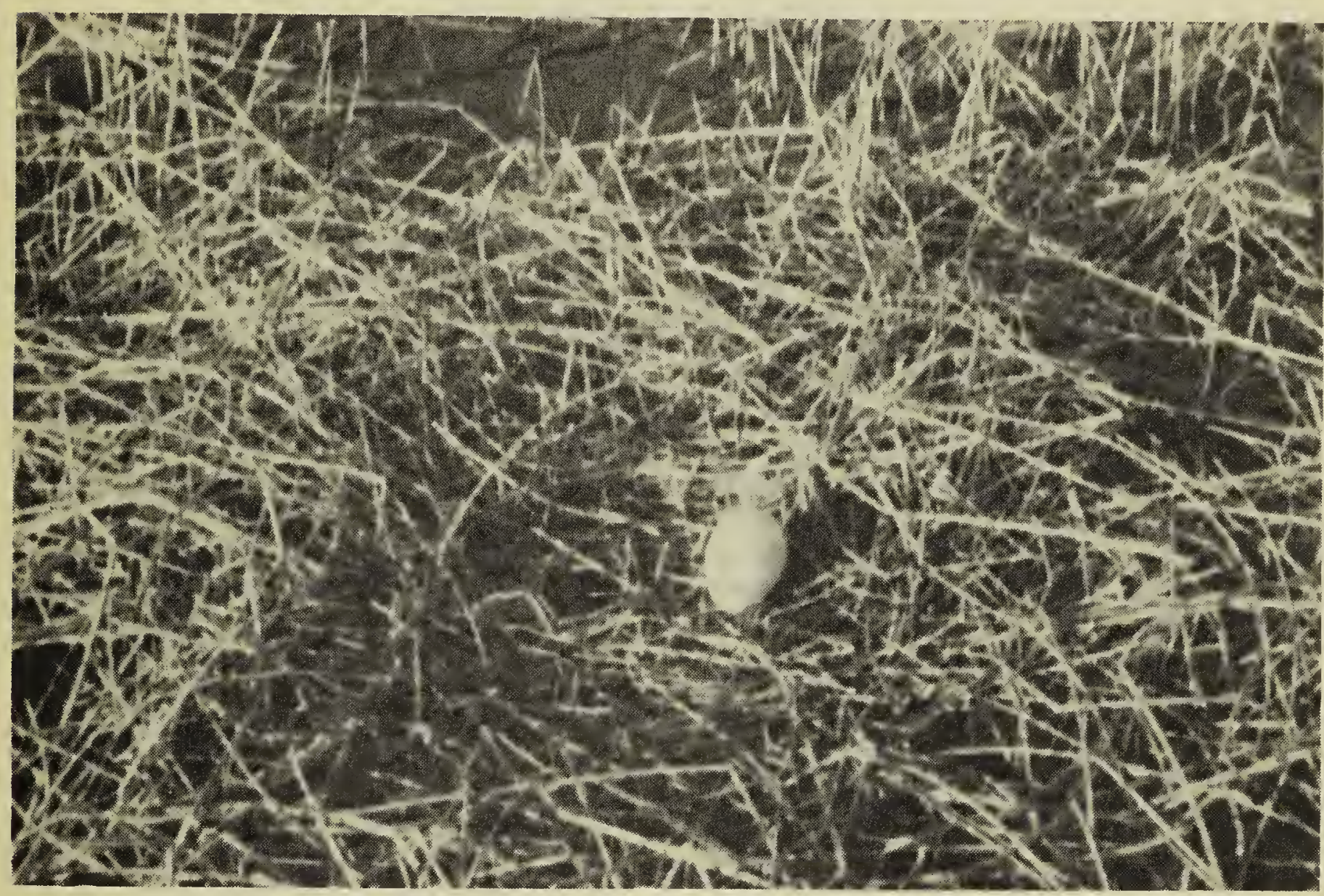

Photo by Dr. Stuart Houston

Sandhill Cranes nested in many places throughout the Yorkton district fifty or more years ago, but settlement forced them to leave most of their former haunts. However, each spring the farmers near the Rokeby Marsh report that at least one pair to be present. Mr. McInnes last found a nest in 1940 .

I have made numerous sorties to the Rokeby Marsh, hoping to find a Sandhill Crane nest, but without success. This year, Johnny Maddaford found a crane nest with one egg on May 5th, while he was trapping muskrats. I visited this nest on May 10th, and found that there was still only one egg, partially incubated. The nest was a platform of dead bulrushes in 21 inches of water.

I had foolishly taken two cameras with me, one for color and one for black and white. I took some pictures of the nest, but each time the cranes flew nearby, I either didn't have time to change focus or I fumbled for the wrong camera. However, the sight of these tremendous birds so close to me, and the sound of their loud, resonant, almost trumpeting call, made an indelible impression on my mind. These birds are the almost vanished symbol of the marsh primeval.

\section{Catching Snowflakes}

\section{Margaret Belcher, Regina}

Perhaps no bird's habits are more picturesque than the waxwing's. I remember one day last March watching Bohemian waxwings drinking on a sun-warmed roof. They sipped the water as it ran down the shingles from the melting snow. I have also read of cedar waxwings chasing and capturing whirling snowflakes. Perhaps they, too, were slaking their thirst, although they may only have been amusing themselves. Has anyone seen Bohemians catching snowflakes? 